\title{
Study of Vocational Education Curriculum for the Formation of Graduates Competency
}

\author{
Luthfiyah Nurlaela ${ }^{1}$ Ratna Suhartini ${ }^{2, *}$ Ekohariadi $^{3,6}$ Elizabeth Titiek Winanti $^{4}$ \\ I Gusti Putu Asto Buditjahjanto ${ }^{3}$ Munoto $^{5}$
}

\author{
${ }^{1}$ Home Economic Department, Faculty of Engineering, Universitas Negeri Surabaya \\ ${ }^{2}$ Fashion Design Vocational Program, Universitas Negeri Surabaya \\ ${ }^{3}$ Informatics Engineering Department, Universitas Negeri Surabaya \\ ${ }^{4}$ Civil Engineering Department, Universitas Negeri Surabaya \\ ${ }^{5}$ Electrical Engineering Department, Universitas Negeri Surabaya \\ ${ }^{6}$ Postgraduate Study Program, Universitas Negeri Surabaya \\ *Corresponding author. Email: ratnasuhartini@unesa.ac.id
}

\begin{abstract}
This study aims to find out: (1) the uniqueness of Vocational Education Ph.D. Program curriculum, Postgraduate Program of Unesa, compared with similar Ph.D programs in Indonesia; and 2) the level of suitability of the Vocational Education Ph.D. Program curriculum with graduate competencies. This type of research is descriptive quantitative, and qualitative. The first aim was solved by analyzing the curriculum documents of the Unesa Vocational Education Ph.D. The program, U.M. Vocational Education Ph.D. The program, and UNY Vocational and Technology Education Ph.D. Program. At the same time, the formulation of the second aim was carried out by distributing questionnaires and interviews with stakeholders, including LPTK lecturers, Polytechnic lecturers, teachers, and schools. Data were analyzed descriptively quantitative and qualitative. The study results showed that: 1) the characteristics of Vocational Education Ph.D. The program is that graduates are expected to develop vocational learning in higher education, vocational education in vocational high schools, and education and training. Profile of Unesa's Vocational Education Ph.D. The program of Unesa is "becoming an academic/scientist/educator/practitioner in various levels in vocational education and science." The profile of the Vocational Education Ph.D. The program of UNY is "producing academics and practitioners." The profile of Vocational Education Ph.D. Program of U.M. is "to be a creative and innovative human being in deepening, expanding and developing vocational education and responsive to the problems of vocational education at national and global scope with a multidisciplinary, interdisciplinary and transdisciplinary approach"; and 2) Most of the respondents (70\%) thought that the Vocational Education Ph.D. Program curriculum was by their needs. The rest, despite stating that the curriculum is by the needs, respondents gave input on the addition of graduate profiles, the addition of courses and studies, and the use of more varied learning media.
\end{abstract}

Keywords: Curriculum, Graduate Competencies, Vocational Education.

\section{INTRODUCTION}

Competence is a description of what a person should do for a particular job. According to Spencer and Spencer[1], competence is a characteristic that underlies a person's effectiveness in a particular job. Competence is also an essential individual characteristic that has a causal relationship with the criteria referred. A competent person has superior performance at work or in certain situations.

In line with this opinion, McClelland [2] suggests that competence is the basis of personal characteristics that become a determining factor in the success or failure of a person to do a job or in a particular situation. In comparison, Moeheriono [3] states that many international management consulting 
firms define competence as an essential characteristic consisting of skills, knowledge, and personal attributes that can distinguish someone who does and does not do it. So basically, competence is a powerful tool to predict the success of someone working in a particular position.

According to Kepmendiknas Number 045/U/2002 [4], what is meant by competence is a set of intelligent, responsible actions that a person has as a condition to be considered capable by the community in carrying out tasks in specific fields of work. Following the Decree of the Minister of Manpower and Transmigration No. 229 of 2003, what is meant by work competence is the workability of each individual, which includes aspects of knowledge, skills, and work attitudes by established standards. Meanwhile, PDRI and Aguirre International [5] argue that competence can apply or use a set of knowledge, skills, and related abilities needed to successfully perform "critical work functions" or tasks in specified work settings. In line with this opinion, Ennis [6] argues that competence is applying or using knowledge, skills, abilities, behaviors, and personal characteristics to successfully perform critical work tasks, certain functions, or operate in specific roles or positions. Based on this definition, it can be seen that competence includes aspects of knowledge, skills, and attitudes in carrying out tasks in specific fields.

Competence is a person's capacity to be demonstrated or displayed in knowledge, skills, and personal characteristics needed to meet special requests or situations. A person can be competent if he can perform a work action with high skills, explain work procedures and work knowledge, and have the right work attitude as an effective and productive worker.

Spencer states that the relationship between employee performance competencies is very close and vital[1]. There is a robust and accurate relevance. Even if employees want to improve performance, they must have competencies following the task or job. There is a very close relationship between competence and performance [3].

Each type of work carried out by a person, including teachers/lecturers, requires a different basis to increase motivation and improve performance, both individually and in organizational performance. One of the demands that must be met by teachers/lecturers in carrying out their activities is that they must be able to carry out their duties professionally. To become a professional teacher, someone must have the competence and ability to transfer knowledge following the substance of science in the scientific field.

Competencies that need to be possessed by a teacher/lecturer are following Government Regulation Number 19 of 2005 concerning National Education Standards, namely pedagogic competence, personal competence, professional competence, and social competence. Several previous studies have proven that competence is related to business performance and individual performance in their careers. As stated by Wasilezuk [7], entrepreneurial competence can affect the company's growth; likewise, Welsa found that business capabilities have a significant impact on business performance[8]. Other studies have found that pedagogical competence affects teacher performance and not professional competence [9]. At the same time, personal competence has a significant influence on teacher performance [10].

The ILO [11], initiated by the G20 developed countries, stated that we are no longer sufficient to train workers to meet their current specific needs; we must ensure access to training programs that support lifelong skills development focus on future market needs. Therefore, it is essential to anticipate the skills required and align the implementation of education with the ever-changing needs of the job market. These changes are applied to the type and level of work qualifications required in work and engineering. Overall the growing demand for nonroutine analytic skills includes creativity, problem-solving, communication, teamwork, and entrepreneurship. These skills can help workers maintain their ability to work and create the ability to survive in the face of change. On the other hand, the demand for routine skills has decreased due to automation, digitization, and outsourcing [12].

As part of the national education system, vocational education plays a very strategic role in realizing a skilled workforce. From various studies that the opportunity to have high and sustainable economic growth of a country will be even more fantastic if it is supported by human resources who have: (1) basic knowledge and abilities to adapt to the demands and dynamics of ongoing developments; (2) higher education levels; (3) skills with a background in science and technology (science and technology); and (4) the ability to produce products both in terms of quality and price, able to compete with other products in the global market.

To anticipate these fundamental changes, vocational higher education must also adapt. 
Curriculum, learning and assessment processes, and various other factors must be pursued in such a way as to produce competent graduates. Competent graduates are assets to improve the economy and stability of the nation. Therefore, vocational education institutions are needed that can contribute to the development of vocational education itself.

The National Standard for Higher Education (SNDikti), as regulated in Permenristekdikti Number 44 of 2015 Article 1, states that the curriculum is a set of plans and arrangements regarding graduate learning outcomes, study materials, processes, and assessments used as guidelines for administering study programs. The Higher Education Curriculum is an institutional mandate that must constantly be updated by developing needs and science and technology as outlined in learning outcomes. Universities as producers of academic human resources need to measure their graduates, whether the graduates produced have abilities equivalent to the abilities (learning outcomes) that have been formulated in the IQF qualification level. Learning outcomes produced by the higher education process are "minimum learning outcomes" obtained through the internalization of knowledge, skills, and attitudes, referred to as "Graduate Competency Standards." Meanwhile, competence is a set of intelligent actions, full of responsibility, which is owned by a person as a condition to be considered capable by the community in carrying out tasks in specific fields of work [4].

Advances in technology and science made the system adopted by every university must be gradually changed. Along with these needs and demands, this curriculum change is an effort to develop these demands. The response to this curriculum change can be seen from the many rules that cover the implementation of the new curriculum, for example, Law Number 14 of 2005 concerning Teachers and Lecturers, Law Number 12 of 2012 concerning Higher Education, Presidential Regulation Number 8 of 2012 concerning the National Qualifications Framework Indonesia (KKNI), Regulation of the Minister of Education and Culture Number 49 of 2014 concerning National Standards for Higher Education (SNPT), and Regulation of the Minister of Education and Culture Number 73 of 2013 concerning Learning Outcomes. Following the KKNI Level, the Higher Education Law Number 12 of 2012 Article 29 concerning Graduate Competence is stipulated by referring to the KKNI, Regulation of the Minister of Research, Technology and Higher Education (Permenristekdikti) Number 44 of 2015 concerning National Standards for Higher Education (SN-Dikti).

Changes in community needs and the development of the business world and the industrial world/DUDI require a new set of competencies that develop old competencies and completely new competencies as new technological demands. Because vocational education is essentially focused on meeting the needs of employment, the redesign of the curriculum must be competency-based with specific standards as a benchmark for achieving its implementation.

In addition, input for the redesign of the vocational curriculum is also obtained from the learning assessment results as the implementation of the existing curriculum is based on achievement and even exceeding graduate competency standards by highlighting content standards, process standards, and assessment standards. The results of all this will be an input for curriculum development, one of which is a redesign or modification. If all this is done continuously, then the intake will be adequate.

Concerning higher education curricula, the U.K. Employers Association The U.K. Government has placed significant pressure on U.K. Higher Education Institutions to equip graduates with the skills necessary for employment and preparation for the workforce. Variously identified as 'key,' 'core' and 'transferable' skills, these have centered on the skills identified in the Dearing Report[13], namely communication, numeracy, information technology, and 'learning how to learn. To this have been added 'commercial attitudes and understanding' [14] and 'self-sufficient' and self-career management. It can also be added to 'digital literacy as a set of skills required to work in an increasingly distributed and digitally enabled context [15].

Based on this description, it is essential to handle the problem of vocational education and employment. One of them is by strengthening vocational education through higher education, which includes how to examine issues of vocational education and the world of work. For this reason, it is necessary to strengthen vocational education through the development of postgraduate programs [16].

This study examines the doctoral curriculum of Vocational Education in Indonesia, namely at the State University of Surabaya (Unesa), Yogyakarta State University (UNY), and Malang State University (U.M.). The first objective is to discover the uniqueness of the doctoral program curriculum for 
PPS Vocational Education Unesa compared to similar doctoral programs in Indonesia. At the same time, the second objective is to determine the level of suitability of the vocational education doctoral curriculum with the competence of graduates.

\section{RESEARCH METHODOLOGIES}

This type of research is descriptive quantitative, and qualitative. The first problem formulation was solved by analyzing the curriculum documents of the Unesa Vocational Education Doctoral Program, U.M. Vocational Education Doctoral Program, and Technology and Vocational Education Doctoral Program at UNY. At the same time, the second problem formulation was carried out by distributing questionnaires and interviews to stakeholders, including LPTK lecturers, Polytechnic lecturers, teachers, and the school.

Data was collected through interviews, questionnaires, and documentation. Interviews are intended to reveal data that does not exist in the questionnaire or documentation. The questionnaire is intended to collect stakeholder response data. Meanwhile, documentation is intended to obtain data on the differences between the Unesa vocational education doctoral program and other vocational study programs at different universities and the required secondary documents. In addition to collecting data on stakeholders, this study also involved two universities as samples: Malang State University (East Java) and Yogyakarta State University (DI Yogyakarta). The two-state universities' considerations are: 1) The previous state universities were both ex-IKIP who received a more comprehensive mandate; 2) The university is located in a different province and, of course, has a different culture; 3 ). The university earlier than Unesa opened a vocational education program, which in this case at Unesa is known as the Vocational education study program.

Data analysis techniques used quantitative and qualitative techniques. Quantitative analysis uses percentages. Qualitative analysis is done by providing narratives and descriptions to answer the research problem.

\section{RESULTS AND DISCUSSION}

\subsection{Comparison of the Distinctiveness of Unesa Vocational Education Doctoral}

\section{Program with Similar Education Doctoral Programs}

This section compares the Curriculum Profiles of the Unesa Vocational Education Doctoral Program, the State University of Malang (U.M.) Vocational Education Doctoral Program and Doctoral Technology and Vocational Education Yogyakarta State University (UNY) are presented.

From observing the data, it can be stated that the profile of the Unesa Vocational Education Doctoral Program is "to be an academician/scientist/educator/practitioner at various levels in the field of education and vocational science." This implies that this study program prepares its graduates to enter as lecturers and teachers for all levels of education in the vocational or vocational field. The study program also prepares its graduates to become instructors in formal, nonformal, and informal education. However, the study program does not rule out the possibility of practitioners interested in exploring vocational education as a provision in developing their insights.

Furthermore, in the U.M. Vocational Education Doctoral Program, the profile of graduates is "to be a creative and innovative human being in deepening, expanding and developing vocational education and being responsive to vocational education problems at national and global scope with a multidisciplinary, interdisciplinary and transdisciplinary approach." This profile does not define a particular profession, such as lecturers, teachers, instructors, and practitioners. In terms of the standard of profiling, it can be said that the profile is less specific.

The profile of the UNY Vocational Technology Education Doctoral Program is "producing academics and practitioners." This program is almost the same as the profile of the Unesa Vocational Education Doctoral Program. However, the connotation of academics generally refers to lecturers, so the emphasis may be on developing lecturers (not teachers). As for Unesa, the development is not only lecturers but also teachers and instructors in nonformal education.

From the description, it appears that the Unesa Vocational Education Study Program does not yet have a specialty (something exceptional, which is a hallmark), which distinguishes it from other similar study programs, especially UNY and U.M. This should be considered and pursued so that the uniqueness of the study program emerges and colors academic and non-academic activities. 
The Industrial Revolution 4.0 or the Fourth Generation Industrial Revolution is an era marked by the emergence of supercomputers, intelligent robots, genetic editing, and neurotechnology development that allows humans to optimize brain function further. Of course, the consequence faced in this era is that higher education must improve to provide the best service and produce superior graduates.

In this regard, one of the things that should be the direction of the development of the Vocational Education Doctoral Program is to provide learning services using blended learning or other methods, which essentially are internet-based learning. In this kind of IoT (internet of thing) era, learning should no longer only rely on face-to-face meetings but must be combined with virtual learning. Students are increasingly mobile, lecturers are increasingly mobile, and the progress of the times demands that everything be fast, practical, effective, and efficient without neglecting the essence of education itself. Then a variety of learning media, learning strategies, and a new education system is needed. No doubt, lecturers must also carry out their learning effectively and efficiently.

Regarding effective and efficient lecturers, Raymond [17] proposes several characteristics. These characteristics include: 1) respecting, 2) making learning attractive, 3) fair evaluation, 4) caring about student success, 5) showing love for their field, 6) being friendly, 7) encouraging questions and discussions, 8) always well-prepared and organized, and 9) make complex material easy.

In this regard, because one of the Vocational Education Doctoral Program objectives is to produce superior teachers and lecturers in the vocational or vocational field, the characteristics of effective and efficient lecturers/teachers must be a concern. Various courses related to the formation of professional teachers and lecturers should be included in the material and lectures.

\subsection{The Level of Conformity of the Vocational Education Doctoral Curriculum with Graduate Competencies}

A questionnaire was distributed to stakeholders to obtain data on the suitability of Vocational Education in doctoral degree curriculum with Graduate Competencies. There were 20 stakeholders gathered, consisting of the Head of the Human Resources Development Agency of the Directorate of Transportation, Director of Aviation Polytechnic
(Surabaya), Director of the Indonesian Aviation Academy (Banyuwangi), Lecturer of the Indonesian Aviation Polytechnic (Surabaya), LPPM Staff of KH A University Wahab Hasbullah (Jombang), and Lecturer of the Muhammadiyah University of Sidoarjo, Lecturer of UPN-Surabaya, and teacher of SMK. More detail can be seen in the following table (table 1).

Table 1. Respondent data

\begin{tabular}{|c|c|c|}
\hline No. & Institution origin & Amount \\
\hline 1. & $\begin{array}{l}\text { Head of Transportation H.R. } \\
\text { Development Center }\end{array}$ & 1 \\
\hline 2. & $\begin{array}{l}\text { Director of Aviation } \\
\text { Polytechnic (Poltekbang), } \\
\text { Surabaya }\end{array}$ & 1 \\
\hline 3. & $\begin{array}{l}\text { Director of the Indonesian } \\
\text { Aviation Academy (API), } \\
\text { Banyuwangi }\end{array}$ & 1 \\
\hline 4. & Lecturer UPN & 1 \\
\hline 5. & Lecturer Poltekbang & 2 \\
\hline 6. & Lecturer API, Banyuwangi & 2 \\
\hline 7. & $\begin{array}{l}\text { Principal of SMKN } 1 \text { Grogol, } \\
\text { Kediri Regency }\end{array}$ & 1 \\
\hline 8. & $\begin{array}{l}\text { Teacher SMK YPM } 8 \\
\text { Sidoarjo }\end{array}$ & 1 \\
\hline 9. & $\begin{array}{l}\text { Lecturer Universitas } \\
\text { Muhammadiyah Sidoarjo }\end{array}$ & 1 \\
\hline 10. & University Student & 5 \\
\hline 11. & Lecturer Unesa & 4 \\
\hline \multicolumn{2}{|c|}{ Total } & 20 \\
\hline
\end{tabular}

Based on table 1, it can be seen that the respondents are pretty varied, seen from their composition representing schools, polytechnics, public and private universities, and teachers, as well as lectures. All of these respondents are in the vocational sector.

Furthermore, based on the collected data from interviews and questionnaires, a summary of the data is presented. 
Table 2. Summary of questionnaire and interview result data

\begin{tabular}{|c|c|c|c|}
\hline No. & Responses from respondents & Frequences & Percentages \\
\hline 1. & The curriculum is by the needs & 14 & $70 \%$ \\
\hline 2. & $\begin{array}{l}\text { The curriculum is appropriate but needs to be improved } \\
\text { by joyful learning. }\end{array}$ & 1 & $5 \%$ \\
\hline 3. & $\begin{array}{l}\text { The curriculum has met expectations and needs, but the } \\
\text { following courses need to be added: } \\
\text { - Manajemen On the Job Training } \\
\text { - On The Job Training Instructor and Supervisor- }\end{array}$ & 1 & $5 \%$ \\
\hline 4. & $\begin{array}{l}\text { The graduate profile needs to be added: "Able to plan and } \\
\text { implement the implementation of Vocational Education." }\end{array}$ & 1 & $5 \%$ \\
\hline 5. & $\begin{array}{l}\text { Graduate profiles need to be added: "Able to understand } \\
\text { and master the "Teaching Factory/Industry" learning } \\
\text { model }\end{array}$ & 1 & $5 \%$ \\
\hline 6. & $\begin{array}{l}\text { The curriculum is appropriate, but it is necessary to add a } \\
\text { comparative study of the implementation of vocational } \\
\text { education in various countries. }\end{array}$ & 1 & $5 \%$ \\
\hline 7. & $\begin{array}{l}\text { The curriculum follows the needs, but it is necessary to } \\
\text { add technical studies. }\end{array}$ & 1 & $5 \%$ \\
\hline & Total & 20 & $100 \%$ \\
\hline
\end{tabular}

The data is deepened with interview data to explore the data on the reasons respondents gave the response. Based on table 2, it appears that most of the respondents (70\%) think that the Vocational Education Doctoral Program curriculum is by their needs. According to respondents, the curriculum is appropriate because respondents need deepening and understanding of pedagogical foundations, application of research methodologies and data analysis, and other studies that can add insight into the latest information. The available courses have served these needs, for example, Green TVET and Public-Private Partnership. Respondents who responded to this consisted of lecturers, students, and teachers.

One respondent gave a response about the need to increase joyful learning. After being traced through interviews, what is meant by joyful learning is the use of more varied learning media. So far, lecturers only rely on LCD media and only display power points. LCD should be used more optimally, for example, by displaying video.

Respondents' suggestions regarding the need to add courses related to on-the-job training (OJT) need to be considered. What is meant, of course, is not the OJT activities but the study of how to manage and evaluate.
It also concerns the role of instructors and supervisors in OJT.

The respondent's suggestion about the need to increase the profile of graduates to plan and implement the implementation of Vocational Education is excellent input and needs to be accommodated. These capabilities may be implicitly included in the profile formulation, but it would be better to be made explicit. Of course, this is an essential input for revitalizing the Vocational Education Doctoral Program curriculum in the future.

Regarding the proposal regarding the addition of graduate profiles to understand and master the "Teaching Factory/Industry" learning model, this needs to be discussed further. The teaching factory (TEFA) is only one of the recommended learning models in the SMK curriculum and other vocational education curricula. Tefa is a forum for schools and the business world/industrial world (DUDI) to jointly develop students' abilities in forming a work culture and industrial culture. Teaching factories can also be a forum for schools to provide products or services, which in its management involve students, teachers, and DUDI. The close relationship between schools and DUDI is a significant factor in the implementation of vocational education, and this is one of the determinants of the success of vocational education [18]. 
In its implementation, the teaching factory is often referred to as a production-based training (PBT) learning model because of its emphasis on production and marketing. PBT is considered as one of the learning models that can be used as a basis for developing learning in vocational education, which includes developing all the potential of students so that they have work insight, work technical skills, employability skills, and carry out self-transformation to the changing demands of the world of work [19].

Teaching Factory and PBT are some of the topics in the Vocational Education Philosophy course. In addition, it is also one of the studies in linearity courses, namely Vocational learning strategies. Linearity courses are provided for students whose educational background is $\mathrm{S} 1$ and S2, not from an educational program. If the ability to implement TEFA is one of the graduate profiles, it is not appropriate because the learning model will continue to develop, and the formulated graduate profile should be relatively stable but flexible enough to accommodate the times.

The respondent's suggestion regarding the need for a comparative study of the implementation of vocational education in several countries does not need to be a stand-alone course so that the credit load does not increase. So far, the study has been part of the Vocational Education Philosophy course. Perhaps in the future, the weight of this study needs to be increased.

Furthermore, regarding the proposal for engineering studies, it has also been accommodated in the Vocational Studies course. In this course, students choose according to their field of vocational expertise. Areas of expertise by the Decree of the DirectorGeneral of Primary and Secondary Education Number 4678/D/KEP/M.K./2016, dated 02-09-2016, consist of areas of expertise: Technology and Engineering, Energy and Mining, Information and Communication Technology, Health and Social Work, Agribusiness and Agrotechnology, Maritime Affairs, Business and Management, Tourism, and Arts and Creative Industries.

Input from stakeholders shows their concern for the existence of the Vocational Education Doctoral Program. Whatever the form of response or input, it is essential for the study program to optimally make more efforts in providing its services.

\section{CONCLUSION AND SUGGESTION}

Based on the results of the study, the conclusions are described as follows: (1) The hallmark of the Unesa Vocational Education Doctoral Program is that its graduates are expected to be able to develop vocational learning in vocational education in universities, vocational education in vocational schools, as well as education and training (training). The Unesa Vocational
Education Doctoral Program profile is "to become an academician/scientist/educator/practitioner at various levels in the field of education and vocational science." The profile of the UNY Vocational Technology Education Doctoral Program is "producing academics and practitioners"; and 2) Most of the respondents (70\%) think that the curriculum of the Vocational Education Doctoral Program is by their needs. Even though they stated that the curriculum was following the needs, the respondents gave input on adding profiles, adding courses — studies, and using more varied learning media.

Based on the conclusion, it is necessary to update the curriculum of the Vocational Education Doctoral Program. The update concerns profiles, course content, and lecture strategies. The next suggestion is that curriculum review should be necessary for any study program and carried out periodically and continuously.

\section{REFERENCES}

[1] LM. Spencer, SM. Spencer, Competence at Work: Models for Superior Performance, New York: John Wiley \& Sons, 1993.

[2] Mc Clelland, "The Concept of Competence," in L.M. Spencer, B.C Spencer, Competence at Work, John Wiley \& Son, New York, 1993.

[3] Moeheriono, Competency-Based Performance Measurement, Surabaya: Ghalia Indonesia, 2009.

[4] Depdiknas, "Permendiknas No. 45 Tahun 2002 tentang Kurikulum Inti Pendidikan Tinggi”, 2002.

[5] PDRI and Aguirre International, "Technical Assistance Guide for Developing and Using Competency Models - One Solution for A DemandDriven Workforce System," PDRI, USA, 2005.

[6] M. Ennis, "Competency Models: A Review of the Literature and the Role of the Employment and Training Administration (ETA)," Department of Labor / Office of Policy Development and Research, Washington, D.C., 2008.

[7] J. Wasilezuk, "Advantageous Competence of Owner/Managers to Growth the Firm in Poland: Empirical Evidence," Journal of Small Business Management, vol. 38, no. 2, pp 88-94, 2000.

[8] H.Welsa, "Influence of Business and Entrepreneurship Against ability Padang Restaurant Business Performance in the Yogyakarta area," Equity, 2006.

[9] M. Hamidi, S. Indrastuti, "Influence Analysis of Competence, Educational Background on Performance Polikteknik Bengkalis Lecturer of Leadership Perspective," Proceedings of the 
National Seminar on Industry and Technology, 2012.

[10] H. Angmalisang, "Influence of Personality on Performance Master Teacher," Elektromatika, vol. $1.1,2011$.

[11] ILO, "World of Work Report 2012: Better Jobs for a Better Economy”, Geneva, 2012.

[12] B.S. Wijanarko, "Sosok Ideal Lulusan Pendidikan Vokasi Indonesia Generasi 2045", Prosiding Seminar Nasional Konaspi 7, Universitas Negeri Yogyakarta, 2012.

[13] R. Dearing, Higher Education in the Learning Society, London: The National Committee of Inquiry into Higher Education, 1997.

[14] J. Hillage, E. Pollard, "Employability: developing a framework for policy analysis (No. RB85). Department for Education and Employment, 1998.

[15] S.P. Atkinson, "Graduate Competencies, Employability, and Educational Taxonomies: Critique of Intended Learning Outcomes," Practice and Evidence of Scholarship of Teaching and Learning in Higher, vol. 10, no. 2, pp. 154-177, 2015.
[16] I.G. Sudirta, R.P. Ariani, M.D. Anggendari,L. Masdarini, "Penyiapan Sumber Daya Manusia di Bidang Vokasional melalui Pengembangan Program Studi Pendidikan Kejuruan Strata Dua", Seminar Nasional Vokasi dan Teknologi (SEMNASVOKTEK), Denpasar-Bali, 2017.

[17] S.M. Raymond, "Effective and Ineffective University Teaching from the Students' and Faculty's Perspectives: Matched or Mismatched Expectations?", Ph.D. Thesis. University of Exeter, 2008. https://pdfs.semanticscholar.org >

[18] T. Kohler, "Patterns of Inter-Institutional and InterOrganizational Collaboration Strengthening The Relationship Between VET and Labour Market For Developing A Professional Work Force," Proceeding International Conference on Vocational Education and Training (ICVET) 2014. Universitas Negeri Yogyakarta, Yogyakarta, 2014.

[19] P. Sudira, TVET Abad XXI, Filosofi, Teori, Konsep, dan Strategi Pembelajaran Vokasional, Yogyakarta: UNY Press, 2016. 